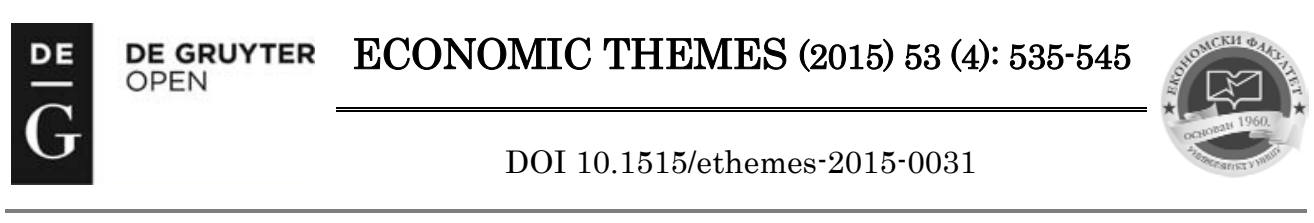

\title{
SIMILARITIES AND DIFFERENCES IN OPERATING THE PERFORMANCE OF AUDIT FIRMS IN SERBIA
}

\author{
Dejan Jakšić \\ University of Novi Sad, Faculty of Economics in Subotica, Serbia \\ $\bowtie$ jaksicd@ef.uns.ac.rs \\ Kristina Mijić \\ University of Novi Sad, Faculty of Economics in Subotica, Serbia \\ 凶ijick@ef.uns.ac.rs
}

Ljiljana Bonić

University of Nis, Faculty of Economics, Serbia

$\bowtie$ ljiljana.bonic@eknfak.ni.ac.rs

UDC

657.6(497.11)

Original

scientific paper

Received:

27.02.2015

Accepted:

19.11.2015

\begin{abstract}
Cluster analysis of audit firms in Serbia was carried out in order to assess the similarities and differences between audit firms. This analysis shows that "Big four" audit firms are significantly different from other audit firms by market position and human potential, but not according to net income. In addition, it can be noted that there are significant differences in observed performance indicators between individual audit firms.
\end{abstract}

Keywords: audit firms, Serbia, performance measures, cluster analysis, Big Four.

\section{Introduction}

Financial statement audit was legally introduced in Serbia as a specialized professional service in 1996. Audit performance is entrusted to audit firms that, in accordance with the theory and practice of audit in the world, should carry out an independent verification of financial statements for their users (new owners of privatized companies, financial investors, banks, state, etc.). 
In the first phase, there were several audit firms which were staffed and ready to perform financial statement audits. Over time, their number was increasing at a faster or slower pace. Today, the audit market in Serbia is highly competitive, which is a consequence of numerous audit firms struggling to attract the limited number of clients. Audit firms use different strategies and approaches in coping with the competition, thus today there exists a wide range of audit firms which are somewhat similar to each other, but often also very different.

The main objective of this paper is a comparison and grouping of audit firms by the similarities and differences in their characteristics. Performance characteristics used for these comparisons are: market share measured by operating revenue, the sustainability of operations in the current conditions identified by net earnings, and the quality and availability of human resources as the most important audit resource which is perceived by the number of employees and the number of certified public accountants (CPAs).

Grouping of audit firms by the similarities and differences in their performances was performed by cluster analysis using the statistical package IBM SPSS Statistics Version 20. The main sources of information are official data provided on the website of the Agency for Business Registers (www.apr.gov.rs), as well as data of Chamber of Certified Auditors of Serbia (www.kor.rs) which is legally obliged to maintain a register of auditing firms.

\section{Audit Firms in Serbia}

According to the Chamber of Certified Auditors, at the end of 2013 there were 60 registered companies in Serbia authorized for audit services. The structure of audit firms according to their size is as follows:

Table 1 Overview of Audit Firms in Serbia According to the Official Classification

\begin{tabular}{|l|c|}
\hline \multicolumn{1}{|c|}{ Size of audit firms } & Number of audit firms \\
\hline Large firm & - \\
\hline Medium firm & 11 \\
\hline Small firm & 48 \\
\hline Micro firm & $\mathbf{6 0}$ \\
\hline Total & \\
\hline
\end{tabular}

Source: Authors' calculation, according to data of Agency for Business Registers as of 31.12.2013 (www.apr.gov.rs, retrieved at 30.09.2014) 
Number of audit firms has increased significantly in recent years, as can be noted on the visual presentation of trends in the number of audit firms in Serbia which is given in the following chart:

Figure 1 Changes in Number of Audit Firms in Serbia in the period 1993-2013

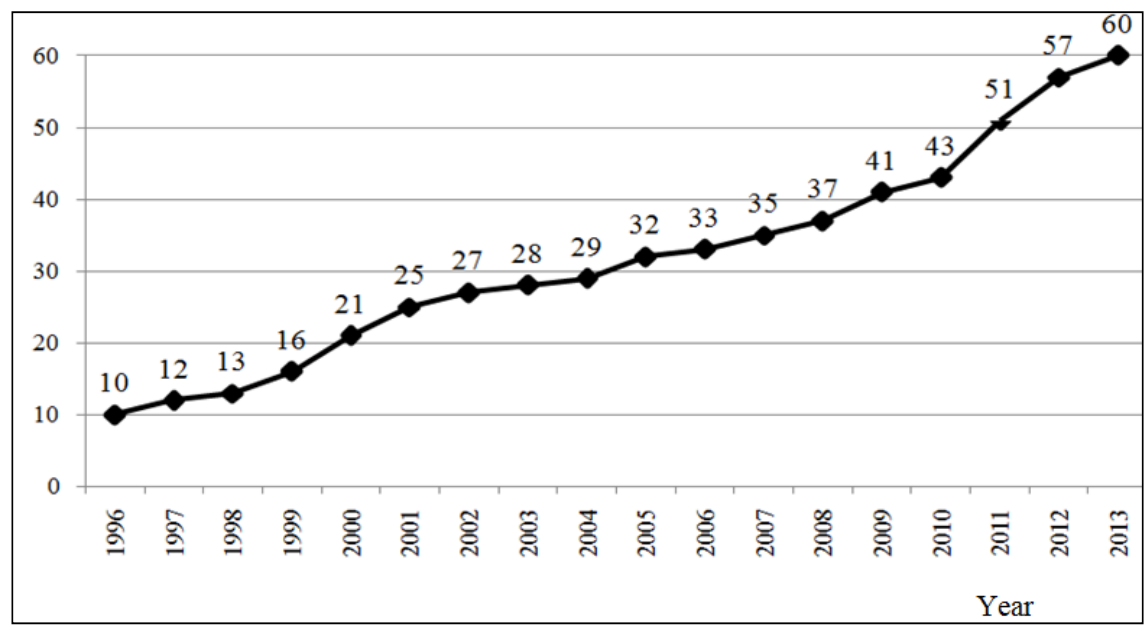

Source: Authors' calculation

Increase in the number of audit firms has not been accompanied by the expansion of the market for audit services, since the number of clients in recent years has not been significantly changed. It even slightly decreased due to the change in the classification of clients by size to micro, small, medium and large legal entities; re-registration of enterprises from public companies to limited liability companies; bankruptcy etc. Audit firms try to compensate for the audit market contraction by providing other services (accounting, tax consulting, transfer pricing, restructuring, etc.), but the share of these services in the revenue of audit firms is still marginal.

Given the required competence in auditing, a key factors of the quality of the audit process are human resources of audit firms. Audit firms must have a sufficient number of qualified staff to be able to carry out financial statements audit in accordance with the highest professional and regulatory requirements. The main pillars of the work of audit are CPAs who are responsible for the quality of the audit engagement. In this context, the number of employees and number of CPAs can be thought of as an important characteristic of an audit firm. 


\section{The Current Situation in Operating the Performance of Audit Firms in Serbia}

There are various indicators which could be used for measurement of operating performance of audit firms. For example, ranking of the top 20 audit firms in Denmark was based on the amount of annual revenue. Furthermore, the audit firms' performance was measured and analyzed according to the number of employees, number of certified auditors, the number of cities where audit firms have offices and a number of clients (Holm, Warming-Rasmussen, 2008, pp. 49-50). Research of operating performance of audit firms in Italy was based on annual revenue and changes in revenue compared to the previous period (Camerano, 2008, pp. 153-155). In the United States, the top 100 audit firms are ranked according to net earnings, operating revenue and number of offices (Inside Public Accounting, 2010, pp. 3-6).

In this paper, operating performance of audit firms in Serbia was measured by following indicators: operating revenue, net earnings, number of employees and number of CPAs. Other data which could present meaningful indicators of operating performance (e.g. number of contracted audit engagements, number of clients, clients perceptions etc.) were not publicly available. This represents a significant limitation to the operating performance analysis. However, the following table shows the descriptive statistics of the main operating performance indicators of audit firms in Serbia.

Table 2 Descriptive Statistics for Audit Firms in Serbia According to the Performance Measures as of 31 December 2013

\begin{tabular}{|c|c|c|c|c|c|c|c|}
\hline \multirow{2}{*}{$\begin{array}{l}\text { Performa } \\
\text { nce } \\
\text { measure }\end{array}$} & \multirow[b]{2}{*}{$\mathbf{N}$} & \multirow{2}{*}{ 当 } & \multirow{2}{*}{ 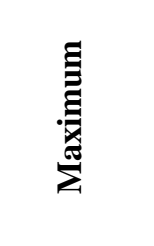 } & \multirow{2}{*}{ సేత్ర } & \multicolumn{2}{|c|}{ Mean } & \multirow{2}{*}{ 悹 } \\
\hline & & & & & 总 & 突 & \\
\hline $\begin{array}{l}\text { Operating } \\
\text { revenue }\end{array}$ & 60 & 677 & $1,157,055$ & $5,119,031$ & 85,317 & 27,918 & 216,251 \\
\hline $\begin{array}{l}\text { Net } \\
\text { earnings }\end{array}$ & 60 & $-1,825$ & 30,532 & 302,765 & 5,046 & 1,002 & 7,764 \\
\hline $\begin{array}{l}\text { Number of } \\
\text { employees }\end{array}$ & 60 & 1 & 169 & 1,124 & 19 & 4 & 34 \\
\hline $\begin{array}{l}\text { Number of } \\
\text { CPA's }\end{array}$ & 59 & 0 & 15 & 210 & 4 & 0 & 3 \\
\hline
\end{tabular}

Source: Authors' calculation, SPSS output 
Operating revenue of audit firms in 2013 varies significantly from 677 thousands of dinars to $1,157,055$ thousands of dinars. Total operating revenue of all audit firms was 5,119,031 thousands of dinars, which is $1 \%$ less than in the previous year. Average operating income was 85,317 thousands of dinars.

As for the net earnings in 2013, five audit firms realized negative net income, while the remaining 55 had positive net income. Total net earnings of all audit firms in 2013 was 302,765 thousands of dinars, which is $17 \%$ more than in 2012. The average net earnings of an audit firm was 5,046 thousands of dinars.

Number of employees in audit firms as of 31 December 2013 also varied widely. There are audit firms that according to official data have one employee, while the largest number of employees in one audit firm is 169 . Given that 19 employees work in an audit firm on average, the total number of employees in all audit firms is 1,124 .

Number of CPAs as of 31December 2013 ranges from 0 to 15 . In total, all audit firms have $210 \mathrm{CPAs}$, which gives an average of 4 auditors (rounded).

Large spread between the minimum and maximum values of the observed variables, as well as high standard deviations, indicate large differences in operating performances of auditing firms and point to the need of their regrouping by similarities in performances. In this way, we can obtain homogenous subgroups characterized by similar performance. This segmentation could be significant to auditing firms in order to assess their competition from a different angle and to identify its position in relation to the others. This could also be of interest to audit clients that want to gain insight into the characteristics of their auditors or possibly think of changing auditors. Namely, if a rotation of auditors is needed due to legislation requirements, audit client may wish to elect the audit firm with similar market position, audit fees and human resources. On the other hand, if the client is not satisfied with its auditor, it may look for an audit firm which is significantly different from the existing one.

\section{Cluster Analysis of Similarities and Differences of Audit Firms in Serbia}

Method of cluster analysis can be used for statistical determination of similarities and differences between audit firms. Cluster analysis consolidates entities according to similarities, in the same time making distinctions between the different entities. Two types of cluster analysis are often employed - hierarchical and non-hierarchical. The main objective of non-hierarchical cluster analysis is a formation of groups in an arbitrary or pre-determined number of groups according 
to the observed characteristics, while hierarchical analysis aims to show the structure of similarities without grouping (Newbold et al., 2010).

Before conducting cluster analysis, it is necessary to consider the correlation between the observed variables (taken arbitrary limit is 0.9 ). If a high degree of correlation between two variables is observed, only one variable that better fits into the pattern should be taken.

Table 3 Pearson Correlation Coefficients for the Observed Performance Measures

\begin{tabular}{|l|r|r|r|r||}
\hline & $\begin{array}{c}\text { Operating } \\
\text { revenue }\end{array}$ & $\begin{array}{c}\text { Net } \\
\text { earnings }\end{array}$ & $\begin{array}{c}\text { Number of } \\
\text { employees }\end{array}$ & $\begin{array}{c}\text { Number of } \\
\text { CPA's }\end{array}$ \\
\hline Operating revenue & 1 & 0.338 & 0.977 & 0.764 \\
\hline Net earnings & & 1 & 0.435 & 0.609 \\
\hline Number of employees & & & 1 & 0.833 \\
\hline Number of CPA's & & & & 1 \\
\hline
\end{tabular}

Source: Authors' calculation, SPSS output

Pearson correlation coefficients for selected performance measurements indicate the high degree of correlation between operating revenue and number of employees. Therefore, the number of employees will not be included in a further clustering since the consideration of human potential of audit firms may be based on the number of CPAs.

\subsection{Non-Hierarchical Cluster Analysis}

Non-hierarchical cluster analysis showed the best results when separating audit firms into two groups. Non-hierarchical cluster analysis has allocated four audit firms in the first group, while the second group contains all other audit firms.

Table 4 Descriptive Statistics for Audit Firm Clusters

\begin{tabular}{|c|c|c|c|c|c|c|}
\hline Clusters & $\begin{array}{c}\text { Performance } \\
\text { measures }\end{array}$ & $\begin{array}{l}\text { No. of } \\
\text { audit } \\
\text { firms }\end{array}$ & Minimum & Maximum & Mean & $\begin{array}{c}\text { Stand. } \\
\text { deviation }\end{array}$ \\
\hline \multirow{3}{*}{ 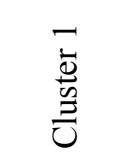 } & Operating revenue & 4 & 508,358 & $1,157,055$ & 841,915 & 265,221 \\
\hline & Net earnings & 4 & 871 & 20,414 & 10,074 & 9,159 \\
\hline & Number of CPA's & 4 & 5 & 15 & 10.50 & 4.20 \\
\hline \multirow{4}{*}{$\begin{array}{c}\sim \\
\dot{\bar{D}} \\
\stackrel{\mathscr{W}}{\Xi}\end{array}$} & Operating revenue & 55 & 677 & 254,186 & 31,769 & 41,720 \\
\hline & Net earnings & 55 & $-1,825$ & 30,532 & 4,770 & 7,667 \\
\hline & Number of CPA's & 55 & 0 & 11 & 3.05 & 2.352 \\
\hline & Missing data & 1 & & & & \\
\hline
\end{tabular}

Source: Authors' calculation, SPSS output 
Four audit firms which were separated in the first cluster are: Deloitte, PricewaterhouseCoopers, Ernst\&Young and KPMG. It is interesting to notice that the results of the statistical analysis fully coincide with the expectations that the "Big Four" audit firms significantly differ in operating performance from all other audit firms.

Attempt of forced formation of more than two clusters does not give satisfactory results. Namely, by increasing the number of clusters to three and four, statistical clustering is done through the division within the cluster of "Big four" audit firms. This means that there is a greater different between "Big four" audit firms than between "Big four" audit firms and all the others. Further forced increase in the number of clusters separates individual firms in individual clusters. Given clusters are not uniform in size which makes cluster analysis impractical.

Since cluster analysis is based on three observed performance indicators, it is interesting to look at which performance indicators the clusters differ the most. For this purpose it is necessary to enforce discriminatory analysis. The results of discriminant analysis are given in the following table:

Table 5 Discriminant Analysis Structure Matrix of Audit Firm Clusters

\begin{tabular}{||l|r|}
\hline \multicolumn{1}{|c|}{ Observed performance measure } & Function \\
\cline { 2 - 2 } & \multicolumn{1}{|c|}{1} \\
\hline Operating revenue & 0.814 \\
\hline Number of CPA's & 0.220 \\
\hline Net earnings & 0.050 \\
\hline \multicolumn{2}{|c|}{ Source: Authors' calculation, SPSS output }
\end{tabular}

Discriminant analysis showed that "Big Four" audit firms differs from other audit firms mostly in operating revenue, and least in net earnings.

Since the obtained parameter of net earnings is very small, the question is whether the clusters in general differ in net earnings. Therefore, it is necessary to conduct additional statistical tests that need to respond to this question. Due to a problem of normal distribution of observed variables (determined by the Shapiro-Wilk test), it is not possible to use parametric tests. Therefore, nonparametric Mann-Whitney U test will be carried out. This test verifies the hypothesis that there is a statistically significant difference between the two groups, respectively, in our case, between the two clusters. If a significance $(p)$ is less than 0.05 , it means that there is a statistically significant difference between clusters. Otherwise, if the $p$-value is greater than 0.05 , we can conclude that the clusters do not differ significantly according to a given parameter. Results of Mann-Whitney U tests are shown in the following table: 
Table 6 Statistical Significance of Cluster Differences in observed Performance Indicators

\begin{tabular}{||l|r|r|r|}
\hline & \multicolumn{1}{|c|}{$\begin{array}{c}\text { Operating } \\
\text { revenue }\end{array}$} & Net earnings & \multicolumn{1}{c|}{$\begin{array}{c}\text { Number of } \\
\text { CPAs }\end{array}$} \\
\hline Mann-Whitney U & 0 & 59 & 11 \\
\hline Wilcoxon W & 1,540 & 1,599 & 1,551 \\
\hline Z & -3.32 & -1.54 & -3.06 \\
\hline Significance (2-tailed) & 0.00 & .13 & 0.00 \\
\hline
\end{tabular}

Source: Authors' calculation, SPSS output

Based on the data, we can conclude:

A) Audit firms in cluster 1 and cluster 2 differ significantly in operating revenue $(U=0, p=0.00)$.

B) Audit firms in cluster 1 and cluster 2 do not differ significantly in net earnings $(U=59, p=0.13)$.

C) Audit firms in cluster 1 and cluster 2 differ significantly in number of CPAs $(U=11, p=0.00)$.

Therefore, it can be concluded that "Big four" audit firms significantly differ from the cluster of other audit firms by the operating revenue and the number of CPAs, but their net earnings are not significantly different from other audit firms.

\subsection{Hierarchical Cluster Analysis}

The objective of hierarchical clustering is to form the structure and hierarchy of similarities and differences between the observed entities. Relationship between audit firms is given in the following dendrogram: 
Figure 2 Hierarchical Cluster Analysis of Audit Firms in Serbia

CENTAR ZA REVIZIJU I EKONOMSKA ISTRAZIVANJA PETERHOF AUDIT

ERSTE REVIZIJA MG

FULL REVIZIJA

PL-AUDITOR

HOLCOM AUDIT

ROSH AUDIT

ACA PROFESSIONAL

BOJIC REVIZIJA

REVIBIL

MC GLOBAL AUDIT

LEITNERLEITNER

ABSOLUTE AUDIT

SAVICA

EUROPOINT

STANOJEVIC AUDITING

AUDITING

MILINKOVIC AUDIT

LIBRA AUDIT

SBV - JANKOVIC

SIGMA REVIZIJA

PAN AUDIT

RPS AUDIT \& CONSULTING

TPA HORWATH AUDI

CONFIDA - REVIZIJA

FINEKS S.J.

PRVA REVIZIJA

NDP AUDIT \& CONSULTINC

REVIZORSKA KUCA-AUDITOR

$\checkmark I N C I C$

SRBO AUDIT

STANISIC-AUDIT

ALFA-REVIZIJA

FINREVIZIJA

KONSULTANT - REVIZIJA

UHY REVIZIJA

GRANT THORNTON REVIZIT

REVIZIJA PLUS-PRO

DIJ-AUDIT

PAN REVIZIJA

KAPITAL REVIZIJA

FINODIT

VIZURA INVENT REVIZIJA

REVIZIJA

PRIVREDNI SAVETNIK - REVIZIJA

MDM REVIZIJA

PKF

BAKER TILLY WB REVIZIJA

HLB DST-REVIZIJA

IEF

EUROAUDIT

MOORE STEPHENS REVIZIJA I RACUNOVODSTVO

$\mathrm{BDO}$

PRICENATERHOUSECOOPERS

ERNST \& YOUNG

DELOITTE

KPMG
Dendrogram using Single Linkage

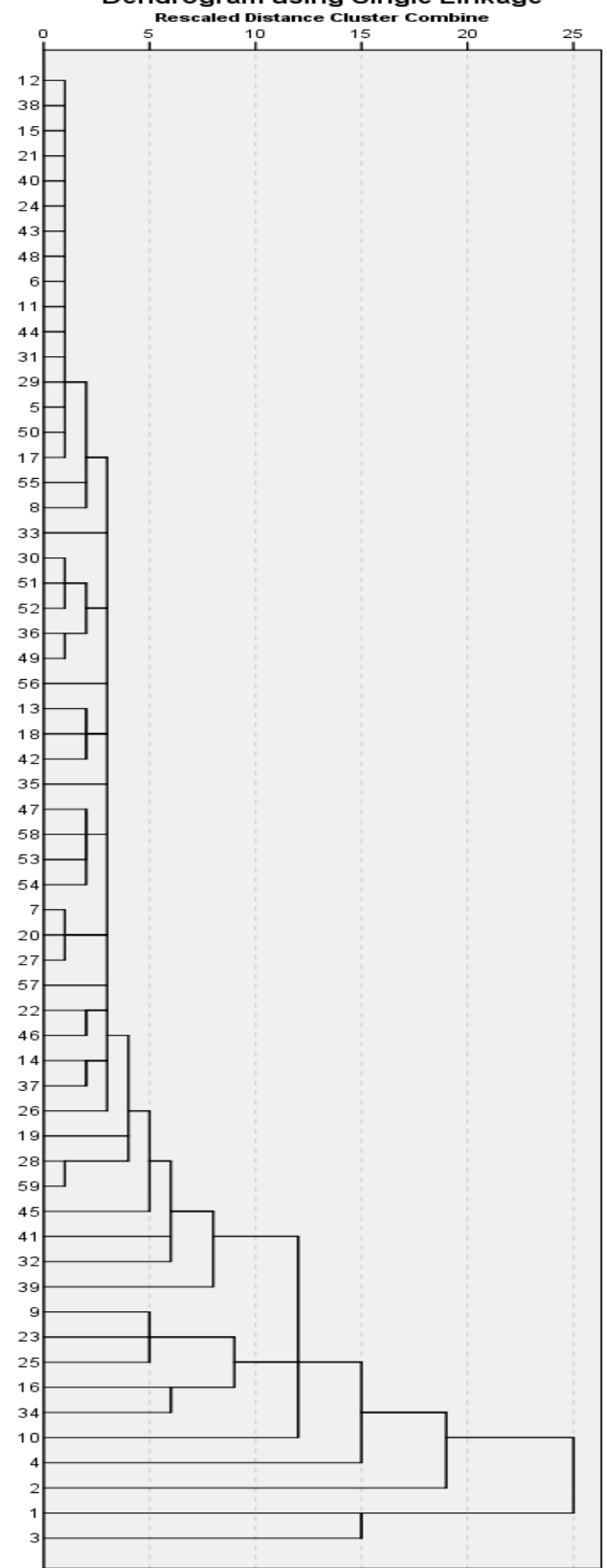


Hierarchical cluster analysis reveals that there are a lot of similarities between smaller audit firms in terms of performance, while the growth and development of audit firms increases the differences from other audit firms.

\section{Conclusion}

The research indicates that the greatest differences in audit firms' performances exist when "Big Four" is compared to other audit firms. However, even in this case, there is no difference in all observed performance measures. "Big four" differs significantly according to market share (measured by operating revenue) and human potential (measured by the number of CPAs). When compared by net earnings, audit firms are more uniform.

The impossibility of forming more than two meaningful clusters indicates that audit firms do not have homogeneous performances. We cannot identify groups of audit firms which are significantly different from other groups of audit firms. Large difference in performance of audit firms is not unusual or unexpected. It is a result of different conditions and circumstances under which audit firms were formed. The wide spectrum of audit firms' performance characteristics indicates a strong competition and confirms that it is still a relatively young market that has not yet been fully profiled.

\section{References}

Agency for Business Registers. (2014). Register of business entities, http://www.apr.gov.rs retrieved at 30.09.2014

Andrić, M., Krsmanović, B., Jakšić, D. (2012). Revizija - teorija i praksa, Bečej: Proleter.

Cameran, M. (2008). "Auditing in Italy - The development of a higly-regulated setting before and after the parmalat case", in R. Quick, S. Turley, \& M. Willekens, Auditing, trust and governance - developing regulation in Europe, Trowbridge: Cromwell press

Chamber of Certified Auditors. (2014). Register of audit firms, http://www.kor.rs retrieved at 30.09.2014

Holm, C., Warming-Rasmussen, B. (2008). "An account of accountants - audit regulation and the audit profession in Denmark", in R. Quick, S. Turley, \& M. Willekens, Auditing, trust and governance - developing regulation in Europe, Trowbridge: Cromwell Press

Inside public accounting. (2010). 2010 top 100 accounting firms, Carmel: the platt group.

Newbold, P., Carlson, L., W., Thorne, B. (2010). Statistics for business and economics, New Jersey: Pearson Education Inc. 


\section{SLIČNOSTI I RAZLIKE U PERFORMANSAMA REVIZIJSKIH FIRMI U SRBIJI}

Apstrakt: U radu je sprovedena klasterska analiza u cilju sagledavanja sličnosti i razlika između revizijskih firmi u Srbiji. Ova analiza je pokazala da se revizijske firme koje pripadaju tzv. „Velikoj četvorci“ značajno razlikuju od ostalih revizijskih firmi po tržišnoj poziciji i kadrovskom potencijalu, a da po ostvarenom neto rezultatu ta razlika nije značajna. Osim toga, može se primetiti da između pojedinačnih revizijskih firmi postoje značajne razlike u posmatranim performansama.

Ključne reči: revizijske firme, Srbija, mere performansi, klasterska analiza, Velika četvorka. 